RASĀYAN J. Chem.

Vol. 13 | No. 4 |2603-2608| October - December | 2020 ISSN: 0974-1496 | e-ISSN: 0976-0083 | CODEN: RJCABP

\title{
FLUORIDE REMOVAL FROM DRINKING WATER BY PRISTINE PUMICE AS ADSORBENT
}

\author{
S. K. Singh, S. Shweta, Mansi Shrivastava*and Shivankar Aggarwal \\ Department of Environmental Engineering, Delhi Technological University, Delhi-110042, India \\ *E-mail: mansis1998@gmail.com
}

\begin{abstract}
Higher levels of Fluoride concentration in drinking water is a matter of serious concern in the present scenario. Controlling the Fluoride levels within the permissible range is of utmost importance to Human beings. The potential of pristine pumice to be used as an adsorbent for the elimination of fluoride from the drinking water is examined. The experiments are performed in batch equilibrium techniques. The influence of varying sorbent concentration, contact time and initial concentration of fluoride was also studied. It has been observed that the fluoride removal is directly proportional to the contact time and sorbent dose. The increase in the reaction period and the sorbent dose improved the quantity of fluoride adsorbed. The present study has indicated that an increase in fluoride initially present results in low efficacy of percentage removal. The adsorption process was found to follow the Langmuir Isotherm.
\end{abstract}

Keywords: Pumice, Adsorption, Fluoride Removal, Batch Techniques

(C) RASĀYAN. All rights reserved

\section{INTRODUCTION}

Water is an indispensable resource for both biotic as well as abiotic components. About $70 \%$ of Earth's surface is covered with water resources out of which $96 \%$ falls under Oceans and Seas and is rendered unfit for drinking due to the high salinity. Ice caps, glaciers, and permanent snow constitute approximately $1.7 \%$ of the total water. Only a small portion of water is available as groundwater which can be accessed by human beings. In India, $67 \%$ of the total population resides in the rural area and groundwater forms the basic source for satisfying their drinking as well as agricultural needs ${ }^{1}$. But nowadays it has become problematic as the water has become severely contaminated due to natural and anthropogenic factors. Water consists of numerous ions like $\mathrm{SO}_{4}{ }^{2-}, \mathrm{Mg}^{2+}, \mathrm{Ca}^{2+}, \mathrm{F}^{-}$etc. Out of this, Fluoride tends to have both a positive as well as a detrimental effect on human health. The prevalence of fluoride in water aids the formation of enamel and bones in children and animals. Fluoride content up to $1 \mathrm{mg} /$ litre is considered beneficial for humans as prescribed by the Bureau of Indian Standards (BIS) ${ }^{2}$. World Health Organisation (WHO) has laid down a limitation on the concentration of fluoride at $1.5 \mathrm{mg} /$ litre in potable water ${ }^{3}$. Consumption of water with fluoride content greater than the permissible limit results in the development of white patches which further leads to dental fluorosis characterized by brown staining followed by pitting of teeth. The prolonged consumption of contaminated water with fluoride concentration exceeding $8 \mathrm{mg} /$ litre results in pain in the joints and brittleness of bones. The intake of fluorides more than $20 \mathrm{mg} /$ day over 20 years or more might result in chronic fluorosis ${ }^{4}$.Dental and skeletal fluorosis are encountered due to the affinity of positively charged calcium ions in bones and teeth to the highly electronegative fluoride ions. Nausea, alterations in the functioning of the kidney, digestive system, central nervous system, nervousness, mottling of teeth, dwarfishness, reduced immunity are the other problems associated with the intake of fluoride-rich water. The severity of the problem depends on various factors like contact time of water with the aquifers, $\mathrm{pH}$, climatic conditions, solubility of fluoride minerals, evaporation rate.

Out of all the elements in the periodic table, Fluorine is known for its highest electronegativity and reactivity. It is the thirteenth most abundant element in the earth's crust. On the virtue of its high reactivity, it does not occur in its natural state in groundwater. The minerals containing fluoride are Apatite $\left[\mathrm{Ca}_{5}\left(\mathrm{PO}_{4}\right)_{3}(\mathrm{Cl}, \mathrm{F}, \mathrm{OH})\right]$, Topaz $\left[\mathrm{Al}_{2} \mathrm{~F}_{2}\left(\mathrm{SiO}_{4}\right)\right]$, Cryolite $\left(\mathrm{Na}_{3} \mathrm{AlF}_{6}\right)$, Fluorspar $\left(\mathrm{CaF}_{2}\right)$, Villiaumite $(\mathrm{NaF})$. These minerals are found to be almost insoluble in water. Therefore, the traces of these minerals will be present in groundwater only when the conditions are favourable ${ }^{6}$.

Rasayan J. Chem., 13(4), 2603-2608(2020)

http://dx.doi.org/10.31788/ RJC.2020.1345967

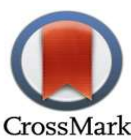


RASĀYAN $J$. Chem.

Vol. 13 | No. 4 |2603-2608| October - December | 2020

\begin{tabular}{c|c} 
Table-1: Effect of Fluoride on Public Health \\
\hline $\begin{array}{c}\text { Fluoride }\left(\mathrm{F}^{-}\right) \\
\text {Concentration }(\mathrm{mg} / \text { litre })\end{array}$ & Health Effect \\
\hline$<0.5$ & Dental carries \\
\hline $0.5-1.5$ & Optimum Dental Health \\
\hline $1.5-4.0$ & Dental fluorosis \\
\hline $4.0-10$ & $\begin{array}{c}\text { Dental and Skeletal } \\
\text { fluorosis }\end{array}$ \\
\hline$>10$ & Crippling fluorosis \\
\hline
\end{tabular}

The occurrence of fluoride is mainly on the account of seepage of rainwater through the ground surface. The presence of fluoride is primarily on the account of the weathering of fluoride-rich rocks due to the rock-water interaction which often depends on the velocity of water, residence time and the solubility of fluoride minerals in the water. Consequently, fluoride from the rocks is leached out and augments the fluoride content in groundwater. Seawater has a fluoride concentration of roughly $1 \mathrm{mg} /$ litre. Groundwater quality in many areas is adversely affected by the fluoride and is presently $67 \mathrm{mg} /$ litre whereas surface water has a fluoride concentration of less than $0.1 \mathrm{mg} / \mathrm{litre}$. Foodstuff like fish and tea also contains fluoride to some extent. Although foodstuffs contain trace quantities of fluoride, it is the drinking water that accounts for $60 \%$ of the total intake of fluoride and makes fluorosis pandemic ${ }^{7}$. The other sources contributing to the deleterious effects of fluoride are toothpaste, phosphate fertilizers, volcanic activity, etc.

Globally, it was estimated that 260 million people were exposed to water consisting of fluoride greater than $1 \mathrm{mg} /$ litre and the greatest problem was reported in China, India, Sri Lanka and few parts of Africa ${ }^{8}$. In India, Andhra Pradesh was the first state to face the issue of excessive fluoride in potable water in the year $1937^{9}$. Approximately $65 \%$ of India's villages and 62 million people are suffering from fluorosis ${ }^{10}$.The contamination was adverse in Andhra Pradesh (1.8-8.4 mg/litre), Haryana (1.5-17 mg/litre), Punjab (0.44$6 \mathrm{mg} /$ litre), Rajasthan (1.54-11.3 mg/litre), Gujarat (1.6-6.8 mg/litre), Tamil Nadu (1.5-3.8 mg/litre) and Uttar Pradesh (1.5-3.11 mg/litre) as per the groundwater testing carried out in the districts in $2201^{11}$.

Due to the deterioration of water quality and subsequent health implications, it is crucial to get rid of fluoride from drinking water before its utilization. For this purpose, various techniques have been adopted like the Nalgonda technique, Adsorption, Electrocoagulation, Membrane Filtration, etc. Adsorption is also known to be effective in the removal of heavy metals. For example, Nano adsorbents aid in the extraction of heavy metals from water ${ }^{12}$. A study reported satisfactory results on the removal of heavy metals and dyes using Nano adsorbents and plant residue ${ }^{13}$. The application of these techniques has been limited by its shortcomings.

In this paper use of Pumice, which is a lightweight volcanic rock has been discussed as an adsorbent for fluoride removal from water. Pumice has been used in the past by researchers also for fluoride removal and has been established as a potent adsorbent because of its large surface area, $90 \%$ porosity and ease of availability in nature. Pumice is known to have a low density as a result of the formation of cavities and cells due to gas expansion which results in the release of pressure. The removal efficiency of fluoride from drinking water by using pristine pumice as an adsorbent and its variation with sorbent dose, contact time and initial fluoride concentration has been discussed.

\section{EXPERIMENTAL}

\section{Chemicals}

The chemicals used in this study were of analytical grade. The experiment was conducted at $25^{\circ} \mathrm{C}$ with a steady agitation speed of $120 \mathrm{rpm}$. In order to achieve a stock solution of $100 \mathrm{mg} / \mathrm{litre}, 221 \mathrm{mg}$ of NaF was added to 1 litre of deionized water. Standard solutions of appropriate concentrations were obtained by serially diluting the stock solution. Pumice Stone powder was procured from a local drug store in Delhi, India. The composition of Pumice is given in Table-2.

\section{Preparation of Pumice}

The Pumice Stone powder was washed with distilled water to remove dust. Further, the mixture was heated at $105^{\circ} \mathrm{C}$ for 24 hours in a hot air furnace to achieve a constant weight. 
RASĀYAN $J$. Chem.

Vol. 13 | No. 4 |2603-2608| October - December | 2020

Table-2: Composition of Pumice ${ }^{14}$

\begin{tabular}{c|c}
\hline Constituent & Percentage (\%) \\
\hline $\mathrm{SiO}_{2}$ & 61.5 \\
\hline $\mathrm{Al}_{2} \mathrm{O}_{3}$ & 15.49 \\
\hline $\mathrm{CaO}$ & 5.9 \\
\hline $\mathrm{MgO}$ & 2.65 \\
\hline $\mathrm{Fe}_{2} \mathrm{O}_{3}$ & 8.4 \\
\hline $\mathrm{K}_{2} \mathrm{O}$ & 1.65 \\
\hline LOI (lost of ignition) & 1.59 \\
\hline
\end{tabular}

\section{Batch Adsorption Study}

\section{Variation of Fluoride with Time}

The effect of time on the amount of fluoride removal was assessed by making use of a fluoride spiked solution of $11 \mathrm{mg} /$ litre. Pumice in the dosage of $2 \mathrm{~g} / 100 \mathrm{~mL}$ at a neutral $\mathrm{pH}$ was added to the solution. The resultant solution was kept in a shaker at $120 \mathrm{rpm}$ and the fluoride concentration was recorded at an interval of 30 minutes.

\section{Variation of Fluoride with Sorbent Dosage}

The impact of sorbent dose on fluoride concentration was carried out by varying the amount of Pumice mixed with the standard solution of $11 \mathrm{mg} /$ litre. The quantity of Pumice powder was kept as $2 \mathrm{~g} / 100 \mathrm{~mL}$, $3 \mathrm{~g} / 100 \mathrm{~mL}, 4 \mathrm{~g} / 100 \mathrm{~mL}$, and $5 \mathrm{~g} / 100 \mathrm{~mL}$ for 150 minutes at $\mathrm{pH} 7$.

\section{Variation with a Concentration of Fluoride}

The effect on removal efficiency due to the fluoride initially present in water was analyzed by preparing standard solutions of working concentration $(8,9,10,11$ and $12 \mathrm{mg} /$ litre). The fluoride in resultant solutions was examined at a neutral $\mathrm{pH}$ after a contact time of 150 minutes.

$$
\text { Removal Efficiency }(\mathrm{E})=\frac{[\text { Initial fluoride }(\mathrm{ppm})-F i \quad \text { fluoride }(\mathrm{ppm})] * 100}{\text { Initial fluoride }(\mathrm{ppm})}
$$

\section{Impact of Contact Time on Removal Efficiency}

The variance of the amount of fluoride with the residence time is depicted in Fig.-1. It has been found that with an increase in the contact time, the amount of fluoride adsorbed has increases when the pumice dosage was kept constant and agitation speed was set at $120 \mathrm{rpm}$. There was a gradual increase in efficiency from $19.09 \%$ at 30 minutes to $25.45 \%$ at 150 minutes. The advancement in removal efficiency was on the virtue of access to the adsorbent spots and dispersion of adsorbent particles in the solution. There was a hike in efficacy at 30 minutes but as time progressed; the performance was not significant due to the saturation of active sites.

\section{Impact of the Sorbent Dosage on Removal Efficiency}

The outcome of Pumice dosage on fluoride spiked solution is illustrated by Fig.-2. The results demonstrated that the fluoride ingested by Pumice is directly proportional to the amount of Pumice in the solution. The increasing adsorbent dosage contributes to a greater number of active sites in the solution which further induces a change in the removal efficiency ${ }^{15}$. When the Pumice dosage was varied from $2 \mathrm{~g} / 100 \mathrm{~mL}$ to $5 \mathrm{~g} / 100 \mathrm{~mL}$, there was an upsurge in removal efficiency from $25.45 \%$ to $42.72 \%$. However, the increase in percentage removal after $4 \mathrm{~g} / 100 \mathrm{~mL}$ is lower as compared to the increase in percentage removal when the adsorbent dose exceeded $3 \mathrm{~g} / 100 \mathrm{~mL}$. This is on the account of the formation of a monolayer of fluoride on the adsorbent surface, shielding affect and agglomeration of adsorbent particles. ${ }^{16}$

\section{Impact of the Initial Concentration of Fluoride on Removal Efficiency}

There was an indirect relationship between the initial concentration of fluoride and the removal percentage, which is portrayed in Fig.-3. As the initial concentration of fluoride began to rise, the removal performance 
RASĀYAN J. Chem.

Vol. 13 | No. 4 |2603-2608| October - December | 2020 declined with constant $\mathrm{pH}$, temperature, agitation speed and Pumice dose. When the initial strength was 8 $\mathrm{mg} / \mathrm{litre}$, the percentage of extracted fluoride was found to be $30 \%$ and when the initial dosage of fluoride rose to $12 \mathrm{mg} /$ litre, the efficacy depreciated to $20 \%$. At lower fluoride concentration, access to a greater number of active spots on the adsorbent leads to a higher removal percentage of fluoride. The fall in efficiency is attributed to increasing fluoride concentration. At a higher initial concentration, the fluoride ions compete for the active spots which leads to a fall in the removal efficiency.

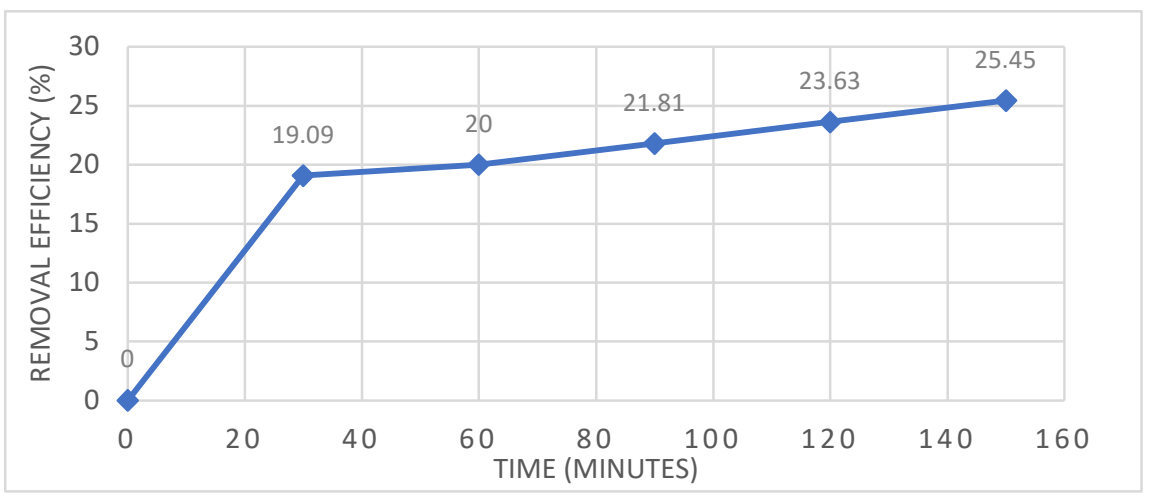

Fig.-1: Impact of Time on Removal Efficiency $\left(11 \mathrm{mg} /\right.$ litre Fluoride Solution, Temperature $25^{\circ} \mathrm{C}$, Neutral $\mathrm{pH}$, $2 \mathrm{~g} / 100 \mathrm{~mL}$ Sorbent Dose)

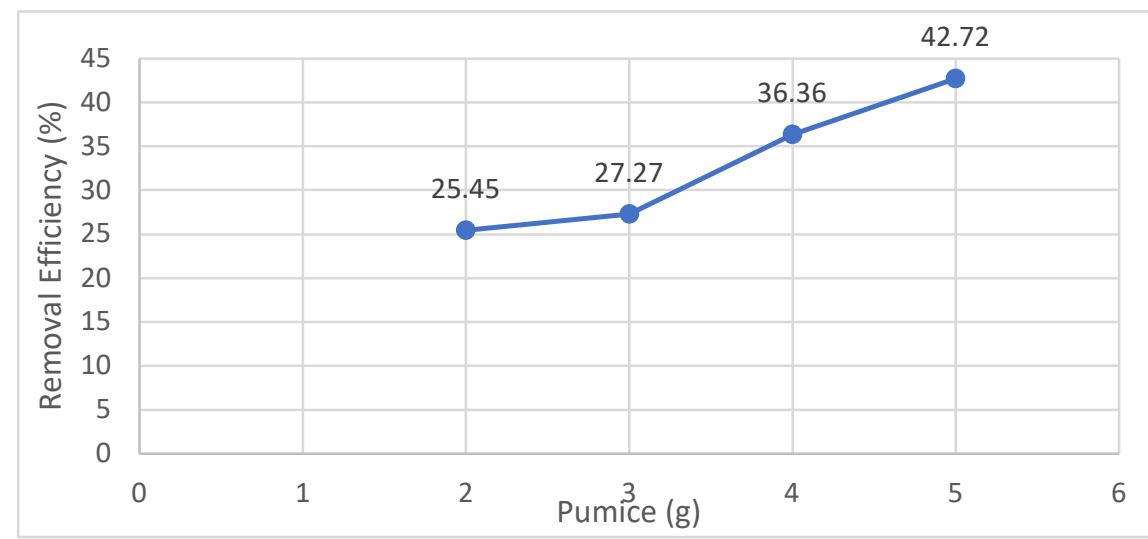

Fig.-2: Impact of Sorbent Dosage on Removal Efficiency $\left(11 \mathrm{mg} /\right.$ litre Fluoride Solution, Temperature $25^{\circ} \mathrm{C}$, Neutral $\mathrm{pH})$

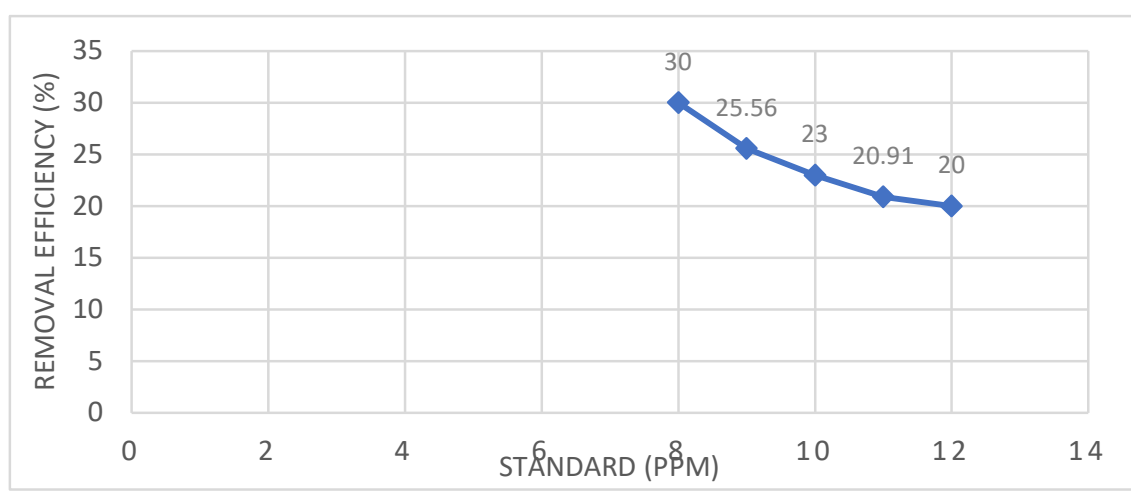

Fig.-3: Impact of Initial Fluoride Concentration on Removal Efficiency (2g/100mL Sorbent Dose, Temperature

\section{Adsorption Isotherms}

$25^{\circ} \mathrm{C}$, Neutral $\left.\mathrm{pH}\right)$

In this study, Langmuir and Freundlich's Isotherms were plotted. By plotting a graph between $\frac{C_{e}}{q_{e}}$ and $\mathrm{C}_{\mathrm{e}}$, the value of $\mathrm{R}^{2}$ was determined. The general equation of Langmuir Isotherm is given by: 
RASĀYAN $J$. Chem.

Vol. 13 | No. 4 |2603-2608| October - December | 2020

$$
\frac{C_{e}}{q_{e}}=\left(\frac{1}{q_{m} K_{L}}\right)+C e\left(\frac{1}{q_{m}}\right)
$$

The $\mathrm{R}^{2}$ value was maximum for Langmuir Isotherm, which was 0.9869 . Hence, it was inferred that the adsorption of fluoride on Pumice follows Langmuir Isotherm. Separation factor, $\mathrm{R}_{\mathrm{L}}$ in the case of Langmuir Isotherm indicates whether the isotherm is favourable or not favourable. It is represented by the equation$3 .^{17}$

$$
R_{L}=\frac{1}{1+K_{L} C_{o}}
$$

Table-3: Values of Separation Factor

\begin{tabular}{c|c}
\hline Value of $\mathrm{R}_{\mathrm{L}}$ & Isotherm \\
\hline $\mathrm{R}_{\mathrm{L}}>1$ & Not Favorable \\
\hline $\mathrm{R}_{\mathrm{L}}=1$ & Linear \\
\hline $0<\mathrm{R}_{\mathrm{L}}<1$ & Favorable \\
\hline $\mathrm{R}_{\mathrm{L}}=0$ & Irreversible \\
\hline
\end{tabular}

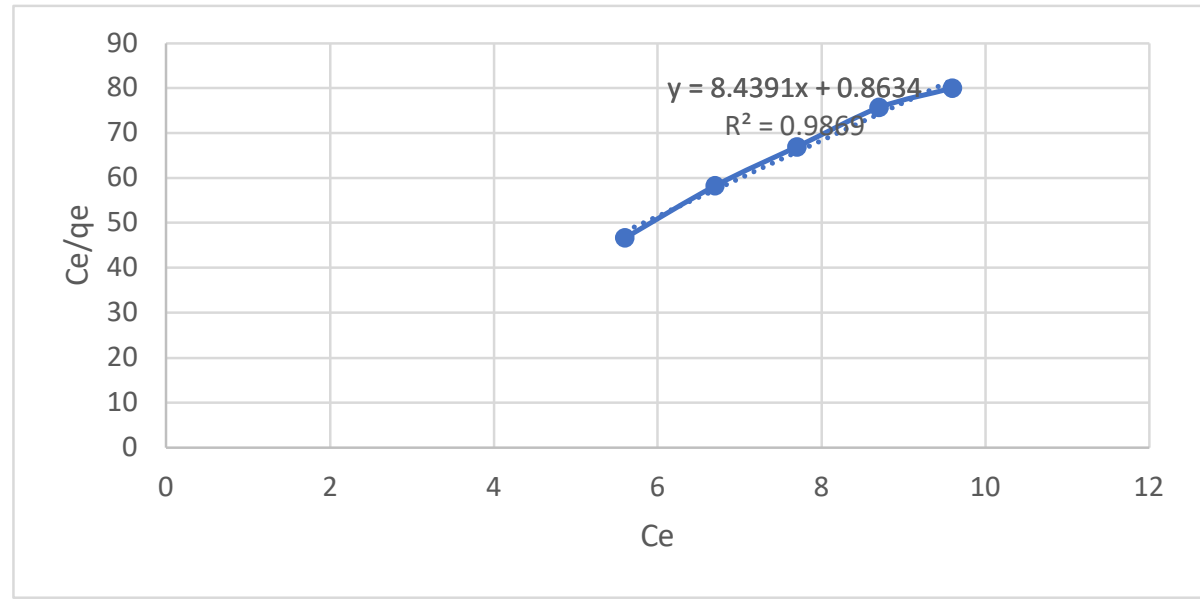

Fig.-4: Langmuir Adsorption Isotherm

\section{CONCLUSION}

Following conclusions are drawn from the study:

- Pristine Pumice can be utilized to extract fluoride effectively from the fluoride contaminated solution on the virtue of its ease of availability and low cost.

- The effectiveness of Pumice as an adsorbent is determined by the actual fluoride concentration in the water, sorbent dosage and the duration for which Pumice is in contact with the solution.

- A direct relationship between contact time and the percentage of fluoride removal was witnessed. As the contact time increased, the ability of Pumice to adsorb fluoride was enhanced. When the reaction time was varied from 30 minutes to 150 minutes, the removal capacity gradually increased from $19.09 \%$ to $25.45 \%$. The removal efficiency was also a function of sorbent dosage. The efficiency experienced a rise when the sorbent dosed was increased. The removal percentage advanced from $25.45 \%$ to $42.72 \%$ when the sorbent dosed was varied from $2 \mathrm{~g} / 100 \mathrm{~mL}$ to $5 \mathrm{~g} / 100 \mathrm{~mL}$.

- With a rise in the initial concentration of fluoride in water, the removal percentage was observed to decrease. The reduction rate fell from $30 \%$ to $20 \%$ as the strength of fluoride solution increased from $8 \mathrm{mg} /$ liter to $12 \mathrm{mg} /$ liter.

- $\mathrm{R}_{\mathrm{L}}$ value for Langmuir Isotherm was 0.013 which indicated that the isotherm was favorable.

\section{ACKNOWLEDGEMENT}

The authors are thankful to the Head of Department of Environmental Engineering and Administration, Delhi Technological University for permitting us to conduct the above study. 
RASĀYAN J. Chem.

Vol. 13 | No. 4 |2603-2608| October - December | 2020

\section{REFERENCES}

1. https://www.business-standard.com/article/economy-policy/70-indians-live-in-rural-areas-census111071500171_1.html

2. Drinking water- specification IS 10500, Bureau of Indian Standards, New Delhi, (1991).

3. https://www.who.int/water_sanitation_health/publications/2011/dwq guidelines/en/

4. A. Jain, S.K. Singh, Open Journal of Water Pollution and Treatment, 1(2),50(2014), DOI: 10.15764/wpt.2014.02006

5. M. Mohapatra, S. Anand, B. Mishra, D. Giles and P. Singh, Journal of Environmental Management, 91(1),67(2009), DOI:10.1016/j.jenvman.2009.08.015

6. A. Jain, S.K. Singh, International Journal of Engineering Science and Innovative Technology, 3, 591(2013).

7. S. Jagtap, M. Yenkie, N. Labhsetwar and S. Rayalu, Chemical Reviews, 112(4), 2454(2012), DOI: $10.1021 / \mathrm{cr} 2002855 \mathrm{k}$

8. J.E.Frencken, Endemic Fluorosis in Developing Countries: Causes, Effects and Possible Solutions(1992).

9. S. Ayoob and A. Gupta, Critical Reviews in Environmental Science and Technology, 36(6),433(2006), DOI: $10.1080 / 10643380600678112$

10. S. Gitte, R. Sabat and K. Kamble, International Journal of Medicine And Public Health, 5(3), 232(2015), DOI:10.4103/2230-8598.161539

11. A. Susheela, Current Science, 77(10),1250(1999).

12. A. Kaushal, SK Singh, Journal of Environmental and Biotechnology Research, 6(1), 96(2017)

13. N. Sharma, D.P. Tiwari, S.K. Singh, Rasayan Journal of Chemistry, 13(2), 1063(2020), DOI: 10.31788/RJC.2020.1325405

14. M. Malakootian, M. Moosazadeh, N. Yousefi, A. Fatehizadeh, Journal of Environmental Science and Technology, 5(4)(2011).

15. P. Mondal, C. Majumder and B. Mohanty, Journal of Hazardous Materials, 150(3), 695(2008).

16. R. Rajumon, J. Anand, A. Ealias, D. Desai, G. George and M. Saravanakumar, Journal of Environmental Chemical Engineering, 7(6),103479 (2019).

17. M. Salim \& Y. Munekage, International Journal of Chemistry, 1(1), (2009), DOI:10.5539/ijc.v1n1p23

[RJC-5967/2020] 